\title{
A New Species of Insect Possibly Invasive for Ornamental Plants in Romania
}

\author{
Ana-Covilca MUNTEAN, Ioana GROZEA* \\ Faculty of Agriculture, Banat's University of Agricultural Sciences and Veterinary Medicine "King \\ Michael I of Romania" Timisoara, 119 Calea Aradului, Timisoara, Romania \\ *corresponding author: ioana_entomol@yahoo.com
}

BulletinUASVM Horticulture 77(2) / 2020

Print ISSN 1843-5254, Electronic ISSN 1843-5394

DOI:10.15835/buasvmcn-hort: 2020.0023

\begin{abstract}
Following the periodic evaluations carried out in the parks of Timisoara (Timis, Romania) which had as main activity the monitoring of harmful insect species, we noticed an interesting species with the ability to jump, which attracted our attention. It has been identified as Scudderia sp. This was not found so far in the western part of Romania or in other areas of the country (to our knowledge). So we started to study it in more detail, to monitor it and to see if there are injuries on ornamental plants. The observations were made during 2019 and 2020, in five representative parks in Timisoara. The insect was reported in two parks. Both immature forms (larvae and nymphs) and adult forms were present, starting with June. The last specimens were observed at the end of September. The population level found in the parks of Timisoara is quite high and the aesthetic damage caused to ornamental plants is clear. The plants that katydids were seen feeding on, were diverse. The most affected of these (about of 30-60\%) were those of rain flower, African daisy flowers and roses.
\end{abstract}

Keywords: damages, monitoring, ornamental plants, parks, Scudderia sp.

\section{Introduction}

Recently, a new species of Orthoptera has been observed damaging ornamental plants, not found so far in the western part of Romania or in other areas of the country (to our knowledge). It has been identified as Scudderia sp., an insect in the family Tettigoniidae (Otte, 1997). As a major group it was included in the group of katydids besides grasshoppers and crickets (Capinera et al., 2004). It is common on the American continent and the popular name known so far is fork-tailed bush katydid (Ross, 2000).

The scientific name given by the European officials in the field (EPPO) is Scudderia sp. (EPPO Global Database, 2002). There are over 21 species of the genus Scudderia, but they are rarely treated worldwide. The lack of information makes it difficult to differentiate between species of the genus. However, the most common seems to be the Scudderia furcata (ITIS, 2020).

As Mahr (2017) considers most of them are herbaceous, and rarely cause significant damage to crops or ornamental plants. The damage can be observed towards the end of summer, in gardens (free plants or pots) due to the feeding of insects with leaves and flowers or from potted plants. Some are nocturnal, but some are active during the day. They can also be seen in open forests and along the edges of plantations in suburban or rural areas. According to Garvey (2018), Scudderia species can damage pears, citrus fruits, plums, nectarines, apricots, blueberries and others plants like roses.

In their place of origin they have natural enemies such as spiders and mantises or some birds and bats (Mahr, 2017). Most studies related 
to katidids are attributed to research on the American continent and especially on the host plants present there (Walker and Cooper, 2019). That is why through this paper, we set out to see what are the preferences of insects on the plants present in the European horticultural space.

\section{Materials and methods}

The insect monitoring observations were made in several important parks in Timisoara (located in the western part of Romania), namely the Botanical Park (45.76055N/21.22548E), the Central Park (45.75139N/21.22111E), the Justice Park (45.74893N/21.22595E), the Park of Roses $(45.75023 \mathrm{~N} / 21.23242 \mathrm{E})$ and the Ion Creanga Park (45.75293N/21.23716E). These were studied during 2019 and 2020. In each park, the insect species was monitored, analyzing the plants on an area of $25 \mathrm{~m}^{2}$ starting from the point of its first observation.

The monitored plant species were chosen on the basis of covering the categories with grassy and woody plants (Tab. 1), depending on their availability on the surface around the first specimens observed but also based on information from the literature. These were the following: wild pansy (Viola tricolor), Rose (Rosa sp.), African daisy flowers (Dimorphotheca pluvialis), rain flower (Dimorphotheca cuneata), chrysanths (Chrysanthemums sp.), black cherry plum (Prunus cerasifera nigra) and weeping mulberry (Morus alba pendula).
In 2019, the analysis of the plants was done starting with April and ending with September and in 2020 the observations were made during April-July. Monthly, movements were made in each park, and 10 herbaceous plants (bushes) and 5 tall plants (small trees) located in the perimeter around the first signal were analyzed. Specimens suspected to be of the genus Scudderia, found in each park were collected in plastic containers and transported to the USAMVBT Phytosanitary Diagnosis and Expertise Laboratory for identification and quantification. The data were centralized and analyzed graphically and statistically (where appropriate).

\section{Results and discussions}

Morphological description of the specimens found in the monitored parks

Almost all the specimens observed on the plants from the parks in Timisoara were identified as belonging to the genus Scudderia. They varied in color but especially in size. Both immature forms (larvae and nymphs) (Fig. 1) and several adults were seen. The specimens found ranged in size from $3.8 \mathrm{~mm}$ to $12.7 \mathrm{~mm}$. The larvae were smaller (3.8 mm-5.5 mm) and the adults were larger (8.9 $\mathrm{mm}-12.7 \mathrm{~mm}$ ). The nymphs showed intermediate values, from $5.6 \mathrm{~mm}$ to $8.8 \mathrm{~mm}$.

The recorded measurements included the body starting with the head and ending with the tip of the circle, without taking into account the antennae (which are extremely long). The

Table 1. Plant species monitored in order to detect the presence of the Scudderia insect in the parks of

Timisoara, in the two years (2019 and 2020)

\begin{tabular}{|c|c|c|c|c|c|c|}
\hline \multirow{2}{*}{\multicolumn{2}{|c|}{ Analyzed plant species }} & \multicolumn{5}{|c|}{$\begin{array}{c}\text { The park/observation place } \\
\text { Present/absent on plant }\end{array}$} \\
\hline & & $\begin{array}{l}\text { Botanical } \\
\text { Park }\end{array}$ & $\begin{array}{l}\text { Central } \\
\text { Park }\end{array}$ & $\begin{array}{l}\text { Justice } \\
\text { Park }\end{array}$ & $\begin{array}{l}\text { Park of } \\
\text { Roses }\end{array}$ & $\begin{array}{c}\text { Ion Creanga } \\
\text { Park }\end{array}$ \\
\hline Wild Pansy* & Viola tricolor & $\mathrm{x}$ & $\mathrm{x}$ & - & $\mathrm{x}$ & $\mathrm{x}$ \\
\hline Rose* $^{*}$ & Rosa sp. & $\mathrm{x}$ & $\mathrm{x}$ & $\mathrm{x}$ & $\mathrm{x}$ & $\mathrm{x}$ \\
\hline African daisy flowers* & Dimorphotheca pluvialis & $\mathrm{x}$ & $\mathrm{x}$ & - & - & - \\
\hline Rain flower* & Dimorphotheca cuneata & $\mathrm{x}$ & $\mathrm{x}$ & - & $\mathrm{x}$ & - \\
\hline Chrysanths* & Chrysanthemums sp. & $\mathrm{x}$ & $\mathrm{x}$ & - & - & - \\
\hline Black Cherry Plum** & Prunus cerasifera nigra & $\mathrm{x}$ & $\mathrm{x}$ & $\mathrm{x}$ & - & $\mathrm{x}$ \\
\hline Weeping mulberry** & Morus alba pendula & $\mathrm{x}$ & $\mathrm{x}$ & $\mathrm{x}$ & $\mathrm{x}$ & $\mathrm{x}$ \\
\hline
\end{tabular}

Note: 10 small plants or shrubs* and 5 tall plants (small trees)** were analyzed in each park 
antennas far exceed the length of the body itself (up to 3 times). As Doubel (2017) says, the abdominal appendages are distinctive in adult forms. We have noticed that in larvae and nymphs, the circus is visible. Indeed the larvae and nymphs are very similar to some spiders, due to their very long and distant legs (Fig. 1).

Generally, these newly observed insects in Romanian parks could not be confused with other species because when they are small (immature) they have a mixture of gray-green color with white stripes. These stripes and white areas are maintained as long as they are in the immaturity stage. The long antennae have distinct white areas, as well as the abdominal and thoracic segments. The larvae are darker than the nymphs. At maturity they turn green.

Other observations related to biology and

behavior

The first specimens observed were on June 9, 2019. They were identified as larvae. The larvae are easier to identify than the nymphs, which appeared in July because they are darker in color and have less mobility. The larvae move by simple walking on the plant or by tight jumps. While the nymphs are more mobile, they move by walking but especially by wide jumps. They are attracted to the colorful flowers (white, purple, yellow, pink, orange) of the plants on which they are installed, often being observed on them. Towards evening they become more active and are placed on the top of the plant (especially on the flower), in the middle of the day being hidden among the leaves.

Regarding the behavior of individuals from a given area (on $25 \mathrm{~m}^{2} /$ monitored park) it was found that they were not disturbed by each other in case of their proximity which confirms the hypothesis and the results obtained by Lichtenstein et al. in 2017, which tested intraspecific competition by cataloging it as low. They are difficult to capture, they seem to feel the presence of danger and they hide quickly. After short rains, they appear more than during the dry period, without humidity. Where there is an irrigation system, or the plants are maintained by periodic watering, their population is higher.

\section{Monitoring results}

After a careful evaluation of the plants and the substrate related to the predetermined area $\left(25 \mathrm{~m}^{2}\right)$ in five parks in Timisoara, we found that the insect Scudderia sp. was not present in all of them. This insect was reported only in two of the those five parks subjected to observation, respectively in Botanical Park and Park of Roses. In the other parks, such as Central Park, Justice Park and in Ion Creanga Park the insect was not reported.

According to the Table 2, both immature forms, larvae and nymphs but also adult forms were present. Most specimens were registered in the Botanical Park, with an average value over the two years, of $\bar{x}=18.57$ compared to the value of $\bar{x}$ $=6.57$ registered in Park of Roses.

By comparing the values obtained in the parks where Scudderia sp. was present (Botanical Park and Park of Roses) in the two years of study it can be seen from the graph in Figure 2, that in 2019 there were more insects than in 2020. Out of a total of 130 specimens recorded in Botanical Park, 89 were observed in 2019 and 41 in 2020. The situation was similar in Park of Roses, out of a total of 46 registered insects, 27 were present in 2019 and 19 in 2020.

The monthly evolution showed that the first specimens (larvae) were reported on June 3 (2019) and on June 14 (2020), then their number gradually increased. Nymphs were also observed in July, and adults appeared in August and Sep-
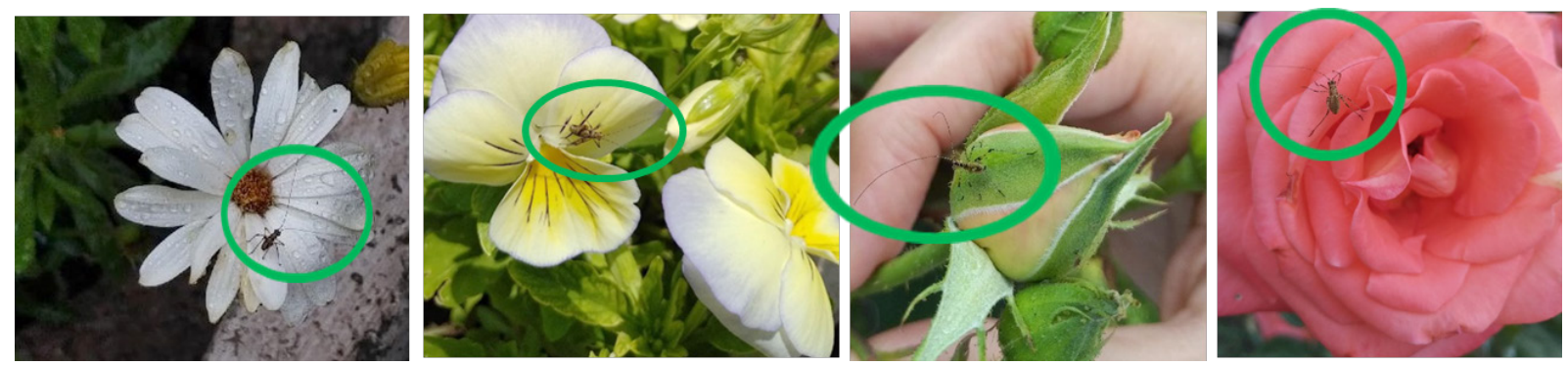

Figure 1. Immature forms (larvae and nymphs) present on the flowers of ornamental plants in the analyzed parks, in 2019 
Table 2. Population level of the species Scudderia sp. registered in the five monitored parks, in the 20192020 period, Timisoara

\begin{tabular}{lccccc}
\hline & \multicolumn{3}{c}{$\begin{array}{c}\text { The park/observation place } \\
\text { Number of specimens found }\end{array}$} \\
\cline { 2 - 6 } Analyzed plant species & $\begin{array}{c}\text { Botanical } \\
\text { Park }\end{array}$ & $\begin{array}{c}\text { Central Park } \\
\text { Wild Pansy }\end{array} 5^{(\mathrm{L})}$ & 0 & $\begin{array}{c}\text { Justice Park } \\
\text { Park of } \\
\text { Roses }\end{array}$ & $\begin{array}{c}\text { Ion Creanga } \\
\text { Park }\end{array}$ \\
\hline Rose & $13^{(\mathrm{N}, \mathrm{A})}$ & 0 & 0 & $2^{(\mathrm{L})}$ & 0 \\
\hline African daisy flowers & $44^{(\mathrm{L}, \mathrm{N})}$ & 0 & 0 & $38^{(\mathrm{N})}$ & 0 \\
\hline Rain flower & $6^{(\mathrm{L}, \mathrm{N})}$ & 0 & 0 & 0 & 0 \\
\hline Chrysanths & 0 & 0 & 0 & 0 & 0 \\
\hline Black Cherry Plum & $1^{(\mathrm{N}, \mathrm{A})}$ & 0 & 0 & $3^{(\mathrm{N})}$ & 0 \\
\hline Weeping mulberry & 0 & 0 & 0 & $3^{(\mathrm{N})}$ & 0 \\
\hline
\end{tabular}

Note: L-larva; N-nimph; A-adult; L,N-larvae and nymphs present; N,A-nymphs and adults present

Statistical values of of the registered population level

\begin{tabular}{cccccc}
\hline$\overline{\mathrm{x}}$ & 18.57 & 0.00 & 0.00 & 6.57 & 0.00 \\
\hline $\mathrm{S}$ & 26.48 & 0.00 & 0.00 & 13.93 & 0.00 \\
\hline $\mathrm{Sx}$ & 10.01 & 0.00 & 0.00 & 5.26 & 0.00 \\
\hline $\mathrm{CV}$ & 142.56 & 0.00 & 0.00 & 211.93 & 0.00 \\
\hline $\mathrm{Sx} \%$ & 53.88 & 0.00 & 0.00 & 80.10 & 0.00 \\
\hline
\end{tabular}

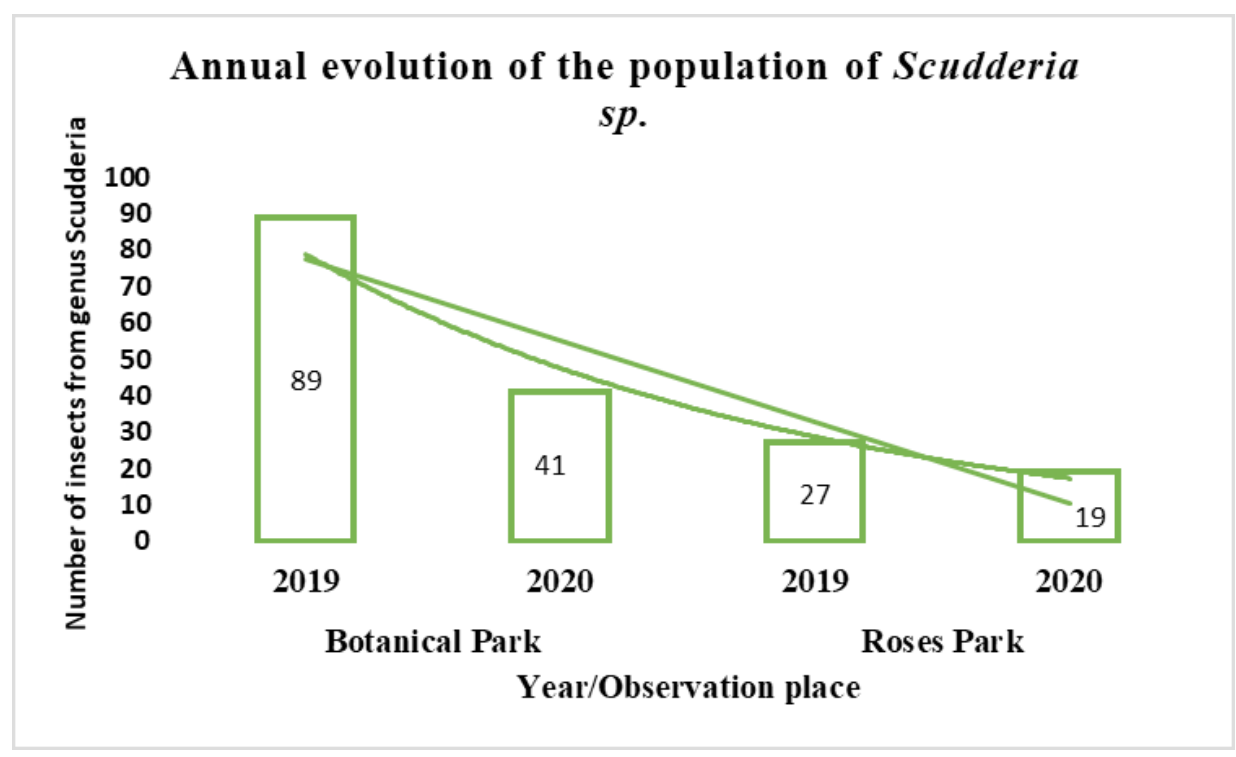

Figure 2. Total values of the evolution of the Scudderia insect population in the two years of observations 
tember. The last insects (adults) were observed on September 28, 2019.

The highest number of larvae and nymphs was observed in late June and early July.

The level of plant damage

of the seven monitored plant species, the Scudderia insect was observed on six of them and feeding on only four of them. So, the plants that can be considered host plants for the insect of the genus Scudderia are the following: rose (Rosa sp.), rain flower (Dimorphotheca cuneata), African daisy flowers (Dimorphotheca pluvialis) and wild pansy (Viola tricolor). We suspect that only accidentally were present on black cherry plum (Prunus cerasifera nigra) and weeping mulberry (Morus alba pendula) because they have been observed in extremely small numbers and have not been observed feeding on these plants. No insects were observed on the chrysanthemum plants (Chrysanthemums sp.). The plants that katydids have been seen feeding on, were the rain flower, African daisy flowers, wild pansy and rose (Fig. 3).
From the analysis of the 10 herbaceous plants or bushes and 5 small trees from each plant species belonging to the two parks with the reported insect, we found that all the plants of the species of rain flower, African daisy flowers and roses from the Botanical Park were affected more or less, indicating a fairly high level. Only 2 wild pansy plants showed some superficial, insignificant perforations. These showed values of injuries (foliar or floral surface affected in relation to the surface of the whole plant or bush) between $30 \%$ and $60 \%$ (Tab. 3 ).

In the Park of Roses, only the leaves of the rose plants were affected. Out of the 10 rose plants analyzed, all were affected in percentages of 30$50 \% /$ bush, with an average of $35 \%$ (Tab. 3). The evolution of the attack on the leaf depended on the number of individuals present. The leaves had superficial pinches on the upper part, then they deepened till the lower part. In the end, the leaves were covered with uneven perforations (Fig. 3). On the flowers, the injuries were done in the form of small circular perforations, at first, then they
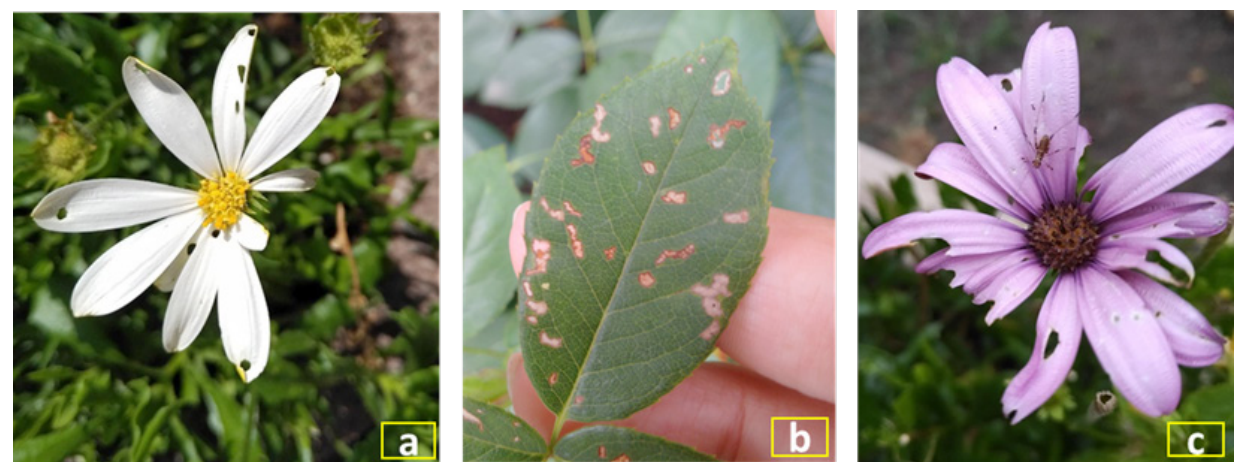

Figure 3. Damages on the analyzed plants: a. circular perforations and partial gnawing of the petals of African daisy flowers; b. irregular perforations on the rose leaves; c. regular perforations and marginal gnawing of Rain flower petals

Table 3. The level (\%) of plant damage in two parks in Timisoara (Botanical Park and Park of Roses)

\begin{tabular}{lcccccc}
\hline & \multicolumn{2}{c}{ Damage to whole plants (10 plants or bushes of each plant species analyzed) \% } \\
\cline { 2 - 6 } $\begin{array}{c}\text { The place of } \\
\text { observation }\end{array}$ & Wild Pansy & Rose & $\begin{array}{c}\text { African daisy } \\
\text { flowers }\end{array}$ & Rain flower & $\begin{array}{c}\text { Black } \\
\text { Cherry Plum }\end{array}$ & $\begin{array}{c}\text { Weeping } \\
\text { mulberry }\end{array}$ \\
\hline Botanical Park & $0.5^{*}$ & $30.0^{* *}$ & $41.5^{* *}$ & $60.0^{* *}$ & $0.0^{*}$ & $0.0^{*}$ \\
\hline Park of Roses & $0.0^{* *}$ & $35.8^{* *}$ & $0.0^{*}$ & $0.0^{*}$ & $0.0^{*}$ & $0.0^{*}$ \\
\hline
\end{tabular}

Note: *none of the 10 analyzed plants/park showed injuries; ** at least one of the 10 analyzed plants/park showed injuries 

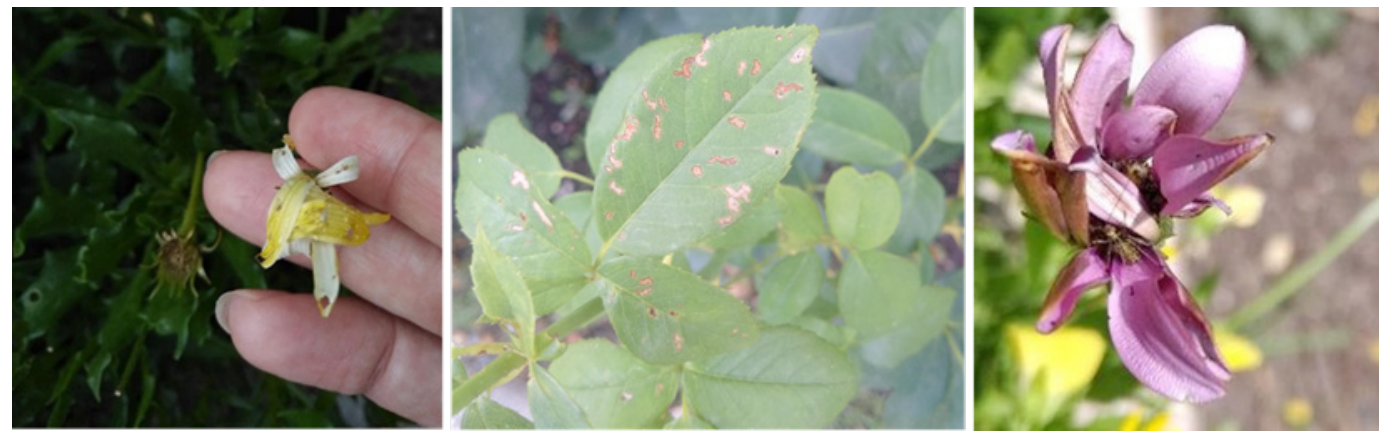

Figure 4. Generalized negative effects of plant bushes damaged by Scudderia sp.

were consumed petal by petal from outside to inside (Fig. 3).

After a while (about 2 weeks), the leaves and flowers of the plants turned brown in the affected zones. The whole process of plant development was affected, and the aesthetic quality decreased considerably (Fig. 4).

The species could be invasive. This hypothesis occurs against the background of sudden appearance and numerical growth in a very short time. It seems to have an extremely high capacity to adapt to new plants and extreme mobility. Basically, the Scudderia sp. insect invaded the parks of Timisoara, and at present there are no known methods of combat but no natural enemies to reduce it in a natural way.

\section{Conclusion}

It is obvious that this insect has been entering the ecosystems of Romania for several years, because the population level found in the parks of Timisoara is quite high and the aesthetic damage caused to ornamental plants is clear. Which is why it is necessary to monitor the species further.

Acknowledgments. We would like to thank the local park administration for making our work easier. This research did not receive any specific grant from funding agencies in the public, commercial, or not-for-profit sectors.

\section{References}

1. Capinera JL, Scott R, Walker T (2004). Field Guide to Grasshoppers, Katydids and Crickets of the United States Cornell University Press.

2. EPPO Global Database (2002). Scudderia sp. (SCUDSP). https://gd.eppo.int/taxon/SCUDSP. Accessed 7.08.2020.

3. Doubell M (2017). Katydid (Orthoptera: Tettigoniidae) bio-ecology in Western Cape vineyards. Master thesis. Stellenbosch University. https://scholar.sun.ac.za. Accesed 12.08.2020.

4. Garvey KK (2018). This Katydid Did. BUG SQUAD Happenings in the insect world. https://ucanr.edu/blogs/ blogcore/postdetail.cfm.

5. ITIS, Integrated Taxonomic Information System (2020). Scudderia Stål, 1873. https://www.itis.gov/servlet/ SingleRpt. Accessed 11.08.2020.

6. Lichtenstein JL, Wright CM, McEwen B, Pinter-Wollman N, Pruitta JN (2017). The multidimensional behavioural hypervolumes of two interacting species predict their space use and survival. Anim Behav.d Doi: 10.1016/j. anbehav.2017.08.010.

7. Mahr S (2017). Katydids. Master Gardener Program Division of Extension Search. University of Wisconsin-Madison. https://wimastergardener.org/article/katydids/.

8. Otte D (1997). Tettigonioidea. Orthoptera Species File 7, 373.

9. Ross HA (2000). American Insects: A Handbook of the Insects of America North of Mexico. CRC Press. ISBN 9780-8493-0212-1.

10. Walker TJ, Cooper TM (2019). Singing Insects of North America (SINA). Genus Scudderia Scudder's bush katydids Checklist of Katydids North of Mexico. https://orthsoc. org/sina/katylist.htm\#Scudderia. Accessed 10.08.2020. 


\title{
Prediction of Botrytis cinerea Risk in Vineyards Based on Weather Indicators
}

\author{
Liliana PIRCALABU*, Elena BRINDUSE, Marian ION
}

Research and Development Institute for Viticulture and Enology, Valea Calugareasca, Romania

*corresponding author: pircalabulilialex@yahoo.com

BulletinUASVM Horticulture 77(2) / 2020

Print ISSN 1843-5254, Electronic ISSN 1843-5394

DOI:10.15835/buasvmcn-hort: 2020.0038

\begin{abstract}
Botrytis cinerea causes grey mould, a major disease occurring in vineyards worldwide, resulting in loss of grape production and wine quality. Predictive models of favorability of Botrytis cinerea were used. Therefore, a series of meteorological data from 2010 to 2019 was used. The results showed that the frequency of years with low risk of Botrytis cinerea was 10\%, medium risk 10\%, high risk $80 \%$. The disease can drastically reduce both yield and wine quality (Ribereau Gayon et al., 1980). The harvest years 2010, 2011, 2012, 2013 and 2014, favored the manifestation of an attack degree of $62.9 \%$ (2012) and 34.2\% (2013). Positive correlations were observed in the case of Broome index and Bacchus index with the duration of sunlight ( $\mathrm{r} 2=0.935)$, respectively $(\mathrm{r} 2=0.944)$ and the sum of the hours of moisture on the leaves $(\mathrm{r} 2=0.833, \mathrm{r} 2=0.848)$. Based on the results a model for prediction of Botrytis cinerea risk will be developed.
\end{abstract}

Keywords: climatic indicators, grey mould, Vitis vinifera

\section{Introduction}

Weather conditions such as temperature, moisture and rainfall have a major impact on the grapevine growing, when the plants are exposed to various climatic parameters extremes. The major weather contrasts generated by daily temperatures surpassing the threshold where grapevine is significantly affected $\left(>35^{\circ} \mathrm{C}\right)$, high sunlight intensity (which generates burn scars on berries skin), higher relative humidity (80-100\%) induce a high susceptibility of grapes for Botrytis cinerea.

The infection filaments can get into the plant tissues, either by penetrating the cuticle or by opened wounds caused by other pathogens, such as powdery mildew, generating small spots of soft tissue on infected berries surface, which grow quickly and always getting into the pulp. On tight bunches, in rainy and high wetness conditions berries split and on their surface grow a gray colour mould, powdery, represented by fungus spores, and in drought conditions and dry air can shrivel the berries. The incidence of sun burns on Chardonnay is high and is correlated with Botrytis cinerea infection severity (Haselgrove 2000, Steel, 2008; Hector, 2008). Although, heavy rainfalls at veraison growth stage can lead to berry splits, supporting Botrytis cinerea development and crop losses.

\section{Materials and methods}

A database on agri-environmental factors related to Valea Călugărească viticultural center was created for a period of 10 years (2010-2019). Based on this, for each harvest year, five climatic indicators were calculated, namely: heliothermal, edaphoclimatic, hydrothermal, for drought, standardized precipitation and Bacchus (Kim et al., 2007) and Broome model (Broome et al., 1995).

TheBacchusriskvaluewascalculatedasfollows: $f(x)=1 /\left[\left(84.37-(7.238 T)+\left(0.156 T^{2}\right)\right]\right.$, where $x$ 
$=$ the Bacchus risk value for a given wet hour and $T=$ mean temperature. This equation represents a correction to the model published by Kim et al. (2007). The Broome risk value was calculated as follows: $f(x)=-2.647866-0.374927 W+0.06160$ $1 T w-0.001511 T w^{2}$; where $x=$ Broome risk for a given wet period, $W=$ duration of surface wetness (h) and $T w=$ mean temperature during the period of surface wetness. The modified Broome risk value was calculated as follows: $f(x)=0.00616 T-$ $0.00015 T^{2}$, where $x=$ Broome risk value for a given wet hour, and $T=$ mean temperature.

Both models took into account the two main periods (windows) of infection corresponding to two growth stages: 'Inflorescences clearly visible' (BBCH 53) and 30\% of 'berries full sized' (BBCH73); during this period the model calculates the infection through conidia developed on inflo- rescences and young bunches. The second infection window appears between 'majority of berries full sized' and 'berries ripe for harvest' (BBCH 89). The Botrytis cinerea severity was ranked according to 7 levels $(0 \%, 5 \%, 10 \%, 25 \%, 50 \%$ and $100 \%)$.

\section{Results and discussions}

The grape growing weather specific for 2010-2019 season, essential for Botryris cinerea occurance is characterised by average temperatures of $19.6^{\circ} \mathrm{C}$, with a maximum of $24.1^{\circ} \mathrm{C}$ (BBCH81) and an air relative humidity of $60 \%$. Rainfall displays poor resources $(45 \mathrm{~mm})$ (Tab. 1). When optimal development conditions are ensured, e.g. temperature between $\left(15-15-23^{\circ} \mathrm{C}\right.$, the evolution of fungus is favourable.

The environmental indexes with synthetic characters: hidro-thermal index (Ih), helio-thermal

Table 1. Monthly average temperature, relative air humidity, rainfall and rainfall standardizat index for 2010-2019 period

\begin{tabular}{ccccc}
\hline Month & T average (\%) & RH (\%) & Rainfall & ISP \\
\hline April & 13.0 & 64.2 & 64.7 & 0.24 \\
\hline May & 17.9 & 69.6 & 97.7 & 0.16 \\
\hline June & 21.9 & 70.0 & 81.1 & -0.01 \\
\hline July & 23.7 & 66.4 & 71.9 & -0.02 \\
\hline August & 24.1 & 60.0 & 45.9 & -0.07 \\
\hline September & 19.1 & 61.7 & 40.7 & -0.08 \\
\hline Mean & 19.6 & 65.3 & 67.0 & 0.04 \\
\hline Maximum & 24.1 & 70.0 & 97.7 & 0.24 \\
\hline Minimum & 13.0 & 60.0 & 40.7 & -0.08 \\
\hline
\end{tabular}

Table 2. Synthetic indices for $2010-2019$

\begin{tabular}{cccccccc}
\hline Year & Ih & IH & $\begin{array}{c}\text { Sunshine } \\
\text { (hours) }\end{array}$ & $\begin{array}{c}\text { Total rainfall } \\
(\mathrm{mm})\end{array}$ & $\begin{array}{c}\text { Mean T of leaf } \\
\text { wetness period } \\
\left({ }^{\circ} \mathrm{C}\right)\end{array}$ & $\begin{array}{c}\text { Leaf wetness } \\
\text { (hours) }\end{array}$ & $\begin{array}{c}\text { Botrytis } \\
\text { occurance } \\
\text { (hours) }\end{array}$ \\
\hline 2010 & 1.94 & 2.78 & 449.6 & 398.6 & 22.9 & 281.6 & 299.4 \\
\hline 2011 & 2.48 & 2.96 & 564.7 & 384.8 & 23.3 & 285.3 & 309.6 \\
\hline 2012 & 2.37 & 3.46 & 139.9 & 501.7 & 20.9 & 52 & 57.8 \\
\hline 2013 & 1.48 & 2.91 & 117.8 & 306 & 20 & 66 & 109.8 \\
\hline 2014 & 2.48 & 2.25 & 329.4 & 515.6 & 20 & 121.3 & 182.8 \\
\hline 2015 & 1.45 & 3.46 & 338.7 & 357.9 & 20.2 & 109.5 & 188.4 \\
\hline 2016 & 2.31 & 3.47 & 406.5 & 443.4 & 21.4 & 155.3 & 183.4 \\
\hline 2017 & 1.84 & 1.94 & 259.4 & 411.3 & 20.9 & 205.5 & 208.5 \\
\hline 2018 & 1.69 & 2.39 & 443.3 & 264.6 & 19.9 & 273.9 & 273.9 \\
\hline 2019 & 2.47 & 2.47 & 372.8 & 436.4 & 17.8 & 229.5 & 253.2 \\
\hline
\end{tabular}




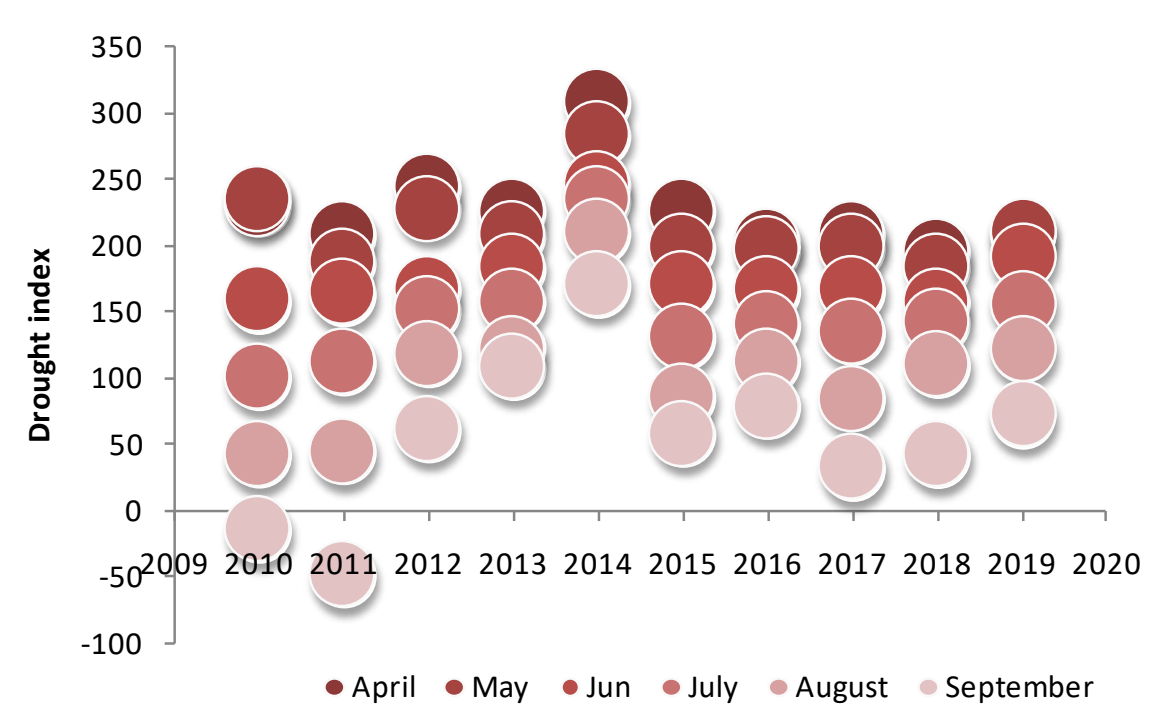

Figure 1. Soil moisture expressed by drought index in the period of 2010-2019

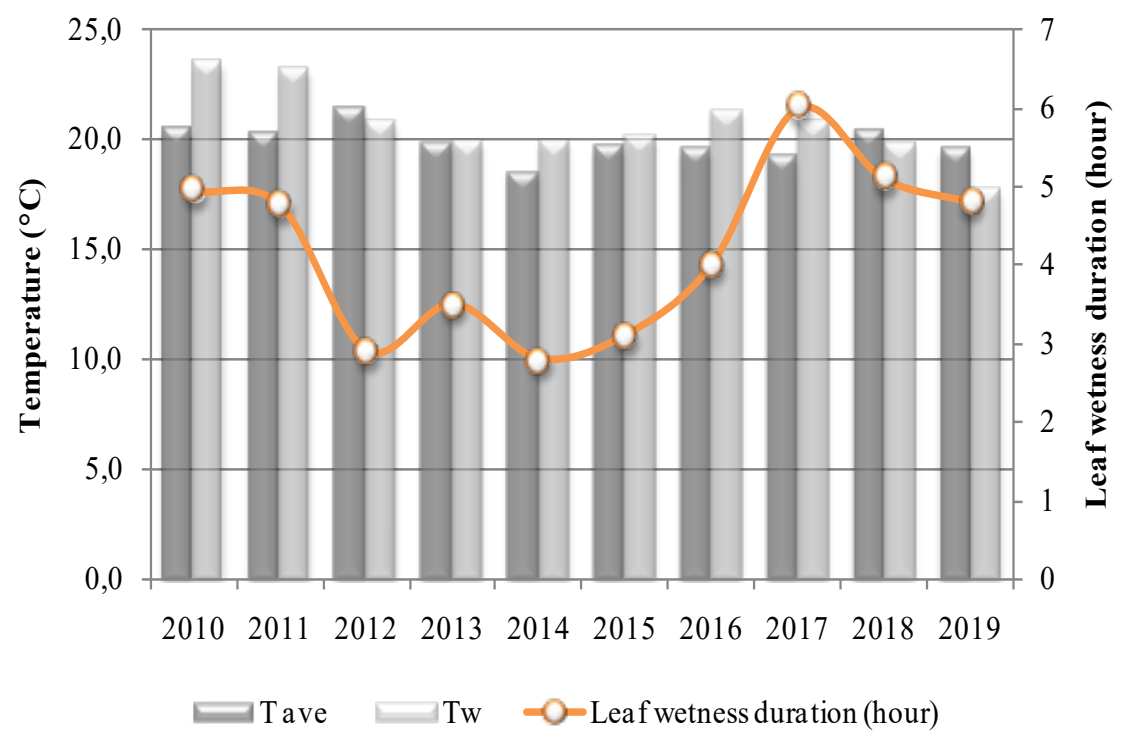

Figure 2. The temperature in the wet period (Tw), average temperature (Tave) and leaf wetness duration (hour) in the period of 2010-2019

index (IH), edafo-climatic index (lec), drought index (IS) and rainfall standardised index (ISP), sunshine duration, highlights the great degree of favourability concerning the growth of grapevine. The hidro thermal index displays in $90 \%$ of years of period of reference the favorability for obtaining of high quality white wines and $10 \%$ of years for white table wines.

The rainfall measured over the flowering stage (BBCH 61) shows values from +14 to $30.7 \mathrm{~mm}$, compared to deficit values $(-21.1 \mathrm{~mm})$ measured over the veraison growth stage (BBCH 81). The frequency of hours with favourable conditions of Botrytis cinerea development were recorded in 2011 (309.6 hours), 2010 (299.4 hours), 2018 (273.9 hours) and 2019 (253.2 hours). In the seasons of 2012 (57.8 hours) and 2013 (109.8 hours), there were no Botrytis cinerea symptoms conditions recorded (Tab. 2).

Sunshine period over 'Inflorescences clearly visible' growth stage (BBCH 53) was short: 117.8 hours compared to 338.7 hours over the 'berries full sized' growth stage (BBCH 79). Favourable conditions for Botrytis cinerea were recorded in 
Table 3. Acumulated Bacchus and Broome index and frequency of Botrytis cinerea appearance for the period 2010-2019

\begin{tabular}{ccccc}
\hline Year & $\begin{array}{c}\text { Accumulated } \\
\text { Bacchus index }\end{array}$ & $\begin{array}{c}\text { Accumulated } \\
\text { Broome index }\end{array}$ & $\begin{array}{c}\text { Frequency of } \\
\text { appearance Botrytis } \\
\text { cinerea (F\%) }\end{array}$ & $\begin{array}{c}\text { Degree of atack } \\
(\%)\end{array}$ \\
\hline 2010 & 3.26 & 3.12 & 188.2 & 62.9 \\
\hline 2011 & 3.41 & 3.62 & 196.1 & 51.9 \\
\hline 2012 & 1.18 & 1.16 & 69.2 & 42.4 \\
\hline 2013 & 1.17 & 1.15 & 59.4 & 34.2 \\
\hline 2014 & 2.94 & 2.74 & 144.3 & 24.9 \\
\hline 2015 & 2.37 & 2.18 & 115.1 & 18.0 \\
\hline 2016 & 2.49 & 2.41 & 127.6 & 31.6 \\
\hline 2017 & 2.19 & 2.10 & 110.6 & 32.6 \\
\hline 2018 & 3.20 & 3.37 & 179.8 & 35.9 \\
\hline 2019 & 2.71 & 2.06 & 108.1 & 20.3 \\
\hline Median & 2.60 & 2.30 & 121.4 & 65.9 \\
\hline $25 \%$ & 1.94 & 1.84 & 98.4 & 181.9 \\
\hline $75 \%$ & 3.22 & 3.18 & & \\
\hline
\end{tabular}

Table 4. All Pairwise Multiple Comparison Procedures (Tukey test):

\begin{tabular}{lcccc}
\hline \multicolumn{1}{c}{ Comparison } & Diff. of Ranks & $\mathrm{q}$ & $\mathrm{P}$ & $\mathrm{P}<0,050$ \\
\hline $\mathrm{F}(\%)$ vs Accumulated Broome index & 254.000 & 6.871 & $<0.001$ & yes \\
\hline $\mathrm{F}(\%)$ vs Accumulated Bachus index & 238.000 & 6.438 & $<0.001$ & yes \\
\hline F $(\%)$ vs Degree of attack & 104.000 & 2.813 & 0.192 & no \\
\hline Degree of attack vs Accumulated Broome index & 150.000 & 4.058 & 0.021 & yes \\
\hline Degree of attack vs Accumulated Bacchus index & 134.000 & 3.625 & 0.051 & no \\
\hline
\end{tabular}

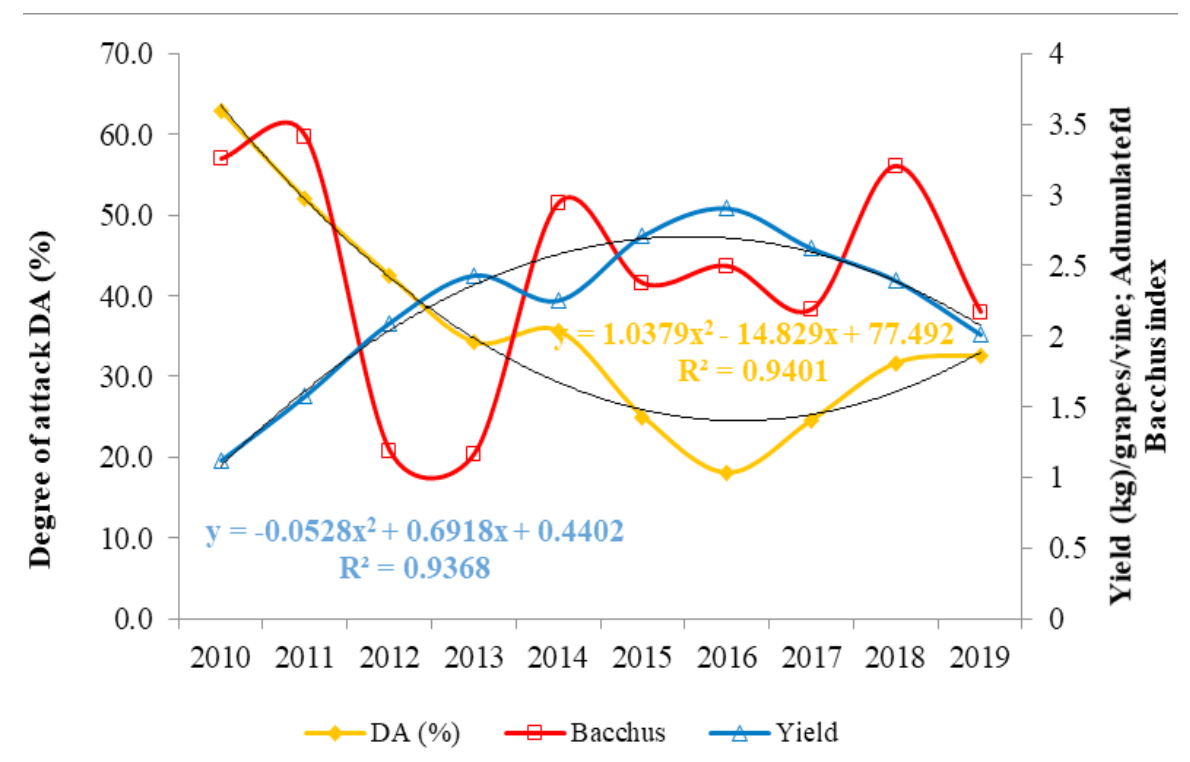

Figure 3. The degree atack (DA\%), Bacchus index and yield (kg/vine) in the period of 2010-2019 
Table 5. Correlations of accumulated Broome index with climatic parameters

\begin{tabular}{lcc}
\hline \multirow{2}{*}{ Weather Parameters } & \multicolumn{2}{c}{ Accumulated Broome index } \\
\cline { 2 - 3 } & Equation & Regression coefficient \\
\hline Sun Shine (duration) (SS) & $0,454+\left(0,00566^{*} \mathrm{SS}\right)$ & $0.935^{* *}$ \\
\hline Total Leaf Wetness (hours) & $0,975+(0,00801 *$ SUM LWD $)$ & $0.833^{*}$ \\
\hline Day degrees (GDD) & $8,855-\left(0,00346^{*} \mathrm{GDD}\right)$ & 0.449 \\
\hline Air temperature during leaf wetness & $-2,667+\left(0,244^{*} \mathrm{~T}\right.$ LWD $)$ & 0.445 \\
\hline Actual temperature & $5,951-\left(0,00197^{*}\right.$ Tutila $)$ & 0.353 \\
\hline Drought index (IS) & $\left.3,481-(0,0070)^{*} \mathrm{IS}\right)$ & 0.296 \\
\hline Helio - thermal index (IH) & $3,568-\left(0,419^{*} \mathrm{IH}\right)$ & 0.271 \\
\hline Standardised Rainfall index (ISP), & $2,445-\left(1,477^{*} \mathrm{ISP}\right)$ & 0.228 \\
\hline Rainfall & $3,291-(0,00224 *$ Rainfall $)$ & 0.210 \\
\hline Relative Humidity (RH) & $4,103-(0,0262 * \mathrm{RH})$ & 0.100 \\
\hline Helio - thermal index (Ih) & $1,596+(0,387 * \mathrm{Ih})$ & 0.193 \\
\hline Edafo - Climatic index(Iec) & $3,172-(0,0514 *$ Iec $)$ & 0.147 \\
\hline Mean Air Temperature & $4,295-\left(0,0955^{*} \mathrm{Tave}\right)$ & 0.09 \\
\hline
\end{tabular}

Table 6. Correlations of accumulated Bacchus index with climatic parameters

\begin{tabular}{|c|c|c|}
\hline \multirow[t]{2}{*}{ Weather Parameters } & \multicolumn{2}{|c|}{ Accumulated Bacchus index } \\
\hline & Equation & Regression coefficient \\
\hline Sun Shine (duration) (SS) & $0,638+(0,00542 * \mathrm{SS})$ & $0.944^{* *}$ \\
\hline Total Leaf Wetness (hours) & $1,125+(0,00774 *$ SUM LWD $)$ & $0.848^{*}$ \\
\hline Day degrees (GDD) & $8,994-(0,00348 *$ GDD $)$ & 0.529 \\
\hline Air temperature during leaf wetness & $-0,419+(0,141 *$ TLWD $)$ & 0.270 \\
\hline Actual temperature & $6,394-(0,00216 *$ Tutila $)$ & 0.408 \\
\hline Drought index (IS) & $3,226-(0,00477 *$ IS $)$ & 0.210 \\
\hline Helio - thermal index (IH) & $3,866-(0,489 * I H)$ & 0.334 \\
\hline Standardised Rainfall index (ISP), & $2,540-(1,306 *$ ISP $)$ & 0.213 \\
\hline Rainfall & $2,915-(0,00105 *$ Rainfall $)$ & 0.104 \\
\hline Relative Humidity (RH) & $2,177+(0,00483 * \mathrm{RH})$ & 0.019 \\
\hline Helio - thermal index (Ih) & $1,447+(0,510 * \mathrm{Ih})$ & 0.268 \\
\hline Edafo - Climatic index(Iec) & $3,419-(0,0609 *$ Iec $)$ & 0.184 \\
\hline Mean Air Temperature & $6,798-(0,216 *$ Tave $)$ & 0.210 \\
\hline
\end{tabular}

2010 (281.6 hours), 2011 (285.3 hours) and 2018 (273.9 hours) sustained by optimal temperatures, respectively: $22.9^{\circ} \mathrm{C}, 23.3^{\circ} \mathrm{C}$ and $19.9^{\circ} \mathrm{C}$. Soil moisture monitoring displays values from high levels of $244 \mathrm{~mm}$ (2014), $168 \mathrm{~mm}$ (2013), $162 \mathrm{~mm}$ (2012), $160 \mathrm{~mm}$ (2019) to low as $112 \mathrm{~mm}$ (2011), $126 \mathrm{~mm}$ (2010), (Fig. 1).

The high air humidity plays a major role in gray mould development, influencing positively both conidia germination and mycelium development.
There is a direct correlation between rainfall and frequency of leaf wetness days, as following:

$$
\text { Rainfall }=455,677-(0,320 * \text { LW })
$$

During 2010-2019 leaf wetness varied between 2,8 hours (2014) and 6 hours (2017), (Fig. 2).

The harvest years 2010, 2011, 2014 si 2018 have displayed specifically favourable weather conditions for Botrytis cinerea development, which determined a more severe level of gray mould 
infection 62.9\% (2010), 51.9\% (2011), 35.6\% (2014) and 32.6\% (2019). In 2015-2017 weather conditions were less favourable for Botrytis cinerea development, displaying lower severity infections: $24.9 \%$., $18.0 \%$ and $24.6 \%$ repectively (Tab. 3.).

Differences between mean values are high, showing a statistically significant difference $(\mathrm{P}=$ $<0.001$ ), in the instance of correlations of Botrytis cinerea frequency (F\%) and accumulated Bacchus index and Broome index, as well as between Broome index and infection severity (Tab. 4).

The environmental weather conditions specific for 2010-2019 and the degree of infection with Botrytis cinerea, influenced in a different way the yield of grapevine plants. The Botrytis cinerea severity of $62.9 \%$ determined a crop loss of $37 \%$, or $1.114 \mathrm{~kg} /$ plant (2010), as in 2016 the yield/ plant was $2.909 \mathrm{~kg} /$ plant (3\%) (Fig. 3).

The modelling equations display distinct correlations for the weather parameters such as sunshine, total leaf wetness for both models: in accumulated Broome index the regression coefficient presenting values between 0.935 and 0.833 (Tab. 5) and in accumulated Bacchus index the regression coefficients are 0.944 and 0.848 (Tab. 6). For estimating the Broome index and Bachus index the following equation can be used:

- Broome index $=0,765+(0,00582 *$ Sun shine $)$ $(0,178 * \mathrm{Ih}),(\mathrm{R}=0.939)$;

- Bacchus index $=-2,552+(0,00575 * \mathrm{SS})+(0,0517$

$* \mathrm{RH})-(0,146 * \mathrm{Ih}),(\mathrm{R}=0.964)$.

\section{Conclusion}

In the present research work, a strong link between some climatic indicators and the severity of diseases with Botrytis was observed. The degree of attack of Botrytis cinerea registered values of $62.9 \%$ which determined crop losses of $37 \%$, res- pectively $1.114 \mathrm{~kg} /$ vine (2010) while in 2016 the production obtained was $2.909 \mathrm{~kg} / \mathrm{vine}(3 \%)$.

Higher occurences of climatic risk of Botrytis cinerea were found in years with the most prelonged wetness period. In case of Broome and Bacchus indicators positive correlations with sunshine duration $\left(r^{2}=0.935\right.$ si $\left.r^{2}=0.944\right)$ and total leaf wetness $\left(r^{2}=0.833\right.$ and $\left.r^{2}=0.848\right)$ were observed. These indicators could be used as early tools in the scheduling the treatment applications against Botrytis cinerea.

Acknowledgments This work was supported by a grant of UEFISCDI Romania, project ERANET 152 "Portable biosensor based device for mapping the risk of grape infection by Botrytis cinerea in the vineyard".

\section{References}

1. Broome JC, English JT, Marois JJ, Latorre BA, Aviles JC (1995). Development of an infection model for botrytis bunch rot of grapes based on wetness duration and temperature. Phytopathology 85:97-102.

2. Haselgrove L, Botting D, Van Heeswijck R, Høj PB, Dry PR, Ford C, Iland PG (2000). Canopy microclimate and berry composition: Effect of bunch exposure on phenolic composition of Vitis vinifera L cv. Shiraz grape berries. Aust. J. Grape Wine Res. 6: 141-149.

3. Kim KS, Beresford RM, Henshall WR (2007). Prediction of disease risk using site-specific estimates 617 of weather variables. New Zealand Plant Protection 60: 128-132.

4. Ribereau-Gayon J, Ribereau-Gayon P, Seguin G (1980). Botrytis cinerea in enology. In: Coley-Smith JR, Verhoeff K, Jarvis WR (Eds.), The Biology of Botrytis. Academic Press, New York, pp. 251-274.

5. Steel C, Greer D (2008). Effect of climate on vine and bunch characteristics: Bunch rot disease susceptibility Journal: Acta Horticulturae, 785(1): 253-262.

6. Valdes-Gomeza H, Fermaud M, Roudet J, Calonnec A, Gary $C$ (2008). Grey mould incidence is reduced on grapevines with lower vegetative and reproductive growth. Crop protection 27: 1174-1186. 